\title{
Precipitation Chemistry of the Rivers State University of Science and Technology (RSUST) campus Air Shed, Port Harcourt, Nigeria
}

\author{
${ }^{1}$ Ubong, I. U. and ${ }^{2}$ Ideria, T.j.k \\ ${ }^{1,2}$ Institute of Pollution Studies (IPS)Rivers State University of Science and Technology.Port Harcourt, Rivers \\ State. Nigeria.
}

\begin{abstract}
Event precipitation study was carried out at three sites (the Institute of Pollution Studies Laboratory ambient environment, Eagle Island and Stadium Road environs) with the following parameters analyzed - $p H$, Conductivity, Turbidity, $\mathrm{Cl}, \mathrm{SO}_{4}{ }_{4}^{2-} \mathrm{NO}_{3}^{-}$, Alkalinity, $\mathrm{NH}_{4}^{+}$using World Meteorological Organization protocols and Standard Methods for water and wastewater protocol (WMO, 1988 and APHA, 1995). The rain water pH was 6.46 obtained at only one station. Oxidation Reduction Potential (ORP) ranged from +29 to $+126 \mathrm{mV}$ for campus, +65 to $+70 \mathrm{mV}$ for Stadium Road and $+126.0 \mathrm{mV}$ for Eagle Island Station. The temperature ranged from $24.6-29.6^{\circ} \mathrm{C}$ across all stations. The Conductivity varied from $3.83-29.4 \mu \mathrm{S} / \mathrm{cm}$ on Campus, $5.2-22.2$ $\mu \mathrm{S} / \mathrm{cm}$ at Stadium road and $10.95 \mu \mathrm{S} / \mathrm{cm}$ at Eagle Island. Salinity ranged from $<0.01-0.01 \%$ at all sites except Eagle Island where levels were not detected. Total dissolved solids ranged from $1.63-18.7 \mathrm{mg} / \mathrm{l}$ on Campus, 2.6 - $13.9 \mathrm{mg} / \mathrm{l}$ at Stadium Road and $6.34 \mathrm{mg} / \mathrm{l}$ at Eagle Island. Dissolved Oxygen ranged from 5.7 $7.3 \mathrm{mg} / \mathrm{l}$ within the campus air shed, while at Stadium air basin, it was $6.5 \mathrm{mg} / \mathrm{l}$. There was no data for Eagle Island. The Chloride values ranged from not detectable $(<1.0)$ to $1.4 \mathrm{mg} / \mathrm{l}$ on campus, not detectable in Eagle Island and Stadium road environs. Sulphate and Phosphates were not detected being less than $1.0 \mathrm{mg} / \mathrm{l}$ and $0.05 \mathrm{mg} / \mathrm{l}$ respectively. Nitrate levels varied from $0.23-1.1 \mathrm{mg} / \mathrm{l}$ on Campus air basin whereas Stadium Road and Eagle Island had 0.31 and $0.41 \mathrm{mg} / \mathrm{l}$ respectively. Ammonia concentration ranged from $<0.02-0.90 \mathrm{mg} / \mathrm{l}$ in campus air basin whereas Stadium Road and Eagle Island had 0.21 and $0.09 \mathrm{mg} / \mathrm{l}$ respectively. Total Hardness ranged from $<0.2-5.8 \mathrm{mg} / \mathrm{l}$ on campus air basin, while it was $<0.2 \mathrm{mg} / \mathrm{l}$ in Eagle Island. Alkalinity ranged from 8.0 - $12.0 \mathrm{mg} / \mathrm{l}$ on Campus air basin while at Eagle Island, it was $12.0 \mathrm{mg} / \mathrm{l}$. Calcium concentration varied from $<0.08-1.2 \mathrm{mg} / \mathrm{l}$ in campus air basin while in others; it was less than $0.08 \mathrm{mg} / \mathrm{l}$. Magnesium ranged from $<0.05-0.7 \mathrm{mg} / \mathrm{l}$ and less than $<0.05 \mathrm{mg} / \mathrm{l}$ in the other two air basins. Correlation Analysis showed strong and positive relationships between Total Alkalinity and Nitrate, Chloride and Nitrate, Nitrate and Calcium, Nitrate and Magnesium. pH only correlated negatively with Oxidation Reduction Potential $($ ORP). Apart from Nitrate, Ammonium ion and Total Alkalinity, all the other ions had either a negative or positive correlation with Temperature. Ammonia did not correlate with any ion. The results from the precipitation studies showed that the rain water quality on Campus is Alkaline ( $p H$ 6.46). The study did not show any contribution from anthropogenic sources as sulphates were not detected. The results of the rain event samples showed that natural sources (soil minerals) are the main contributors to rain chemistry. The study is significant in that it has provided information on the state of the chemical composition of rainfall, the $\mathrm{pH}$ status of rain water and the need for further study.
\end{abstract}

Keywords: Rain chemistry, RSUST campus, environs, Port Harcourt

\section{Introduction}

Pollutants are removed from the atmosphere during wet and dry periods (NADP, 1989. Wet deposition is therefore the transfer of a substance from the atmosphere to the earth's surface either as rain, snow or hail (Fowler, 1980; Dorland and Semb, 1980). The chemistry of precipitation has been the subject of detailed studies by various research scientists all over the world (Mc Coll, 1980; Mamane et al., 1980; Samson, 1984; Saxena et al., 1984; Dayan et al., 1986; Mamane, 1987; Gillet and Ayers, 1989; WMO, 1989; and Reynolds et al., 1990).

Most of these studies focused on acidity and on the effects of the deposition on the ecosystems. The acidity of precipitation is frequently used as a quantitative measure of the effects of these acids on aquatic and terrestrial systems (WMO, 1988).

Precipitation is the settling out of atmospheric aerosols in solution or suspension by various processes. In meteorology, the term 'precipitation' is used for any aqueous deposit in liquid or solid form derived from the atmosphere. Consequently, the term refers to various liquid and frozen forms of water like rain, snow, hail, dew (Ayoade, 1998). However, only rain and snow make significant contributions to precipitation totals. In the tropics, the term rainfall is interchangeable with precipitation since snow is generally absent except on some high mountains like the Kilimanjaro in East Africa. Snowfall is difficult to measure accurately and most 
precipitation records are in fact rainfall equivalent records. In this report therefore, rainfall and precipitation are used interchangeably.

Presently at the international level, there are over 1000 stations around the world measuring precipitation chemistry (WMO, 1989). These stations range from global, regional to local. In Nigeria, some studies have been done but the results are usually, not in the public domain (Faithlink, 2001; Unical Consult, 1991 and Ubong, 2008). Apart from some ad hoc studies, very little direct study has been conducted in the Niger Delta to draw specific conclusions on precipitation chemistry. Preliminary evidence and results from studies conducted elsewhere show that precursors to acid deposition are responsible for most problems reported in those temperate places. In our region, there is a wide gap in knowledge, which this research study seeks to abridge.

The aim of this study was to determine precipitation chemistry, identify and quantify constituents of atmospheric precipitation as well as providing inter-relationships existing between critical indicator parameters and provide a framework for further studies.

The study area was Port Harcourt, which lies within Latitudes $4^{\circ} 43^{\prime} 07^{\prime \prime}-4^{\circ} 54^{\prime \prime} \mathrm{N}$; and Longitudes $6^{\circ}$ $56^{\prime} 04^{\prime \prime}-7^{\circ} 03^{\prime} 20^{\prime \prime} \mathrm{E}$. The mean annual rainfall is over $2000 \mathrm{~mm}$ and mean annual temperature is $29^{\circ} \mathrm{C}$ (NMS, 1998). The population is well over 1 million. The study site was the Rivers State University of Science and Technology and environs (Fig. 1), which is located within Port Harcourt metropolis, in the Niger Delta sedimentary basin of Nigeria.

In our own environment, it is generally believed that precipitation is acidic especially with frequent flaring of natural gas and the perceived notion of emission of inorganic gases $\left(\mathrm{SO}_{\mathrm{X}}, \mathrm{N} 0_{\mathrm{X}}\right.$, etc. $)$ into the atmosphere. Reynolds et al. (1989), carried out a study of the chemical composition of Bulk precipitation across the mountains of Snowdonia in UK; ranging in altitude from 90 to $891 \mathrm{~m}$ above sea level. Bulk precipitation chemistry was monitored monthly for 18 months from 10 mountain sites and one coastal site in North Wales of U.K. The precipitation was acidic although ionic composition was dominated by sea - salts.

Mamane (1987) investigated the chemistry of precipitation in Israel. Rain event samples were collected at various sites in the winter of 1979/80. The results of the 130 rain event samples collected during the years showed that natural sources, sea salt and soil carbonates were the main contributors to rain chemistry. Anthropogenic contribution was insignificant. The $\mathrm{pH}$ data showed that rain in Israel is acidic only in a few cases and averaged 6.5. The rain in Israel is simultaneously high in sea salt and soil components (Mamane, 1987).

In other studies, in places like Western Europe and North Eastern USA, rain water with low pH values has been observed consistently (Galloway et al., 1976; Likens, 1976; Likens Butler, 1981; Cowling, 1982). In these studies, the protons in acid rain have been correlated largely with inorganic anions such as sulphate and nitrate. Literature sources also showed that the "Norwegian interdisciplinary research programme" Acid precipitation - Effects on forest and fish (The SNSF - Project) was launched in 1972 in response to a wide spread concern especially in the Scandinavian countries, that acid precipitation was causing changes to the natural environment. The main research efforts were directed towards possible threats to forest and freshwater fish (NIRP, 1981).

While there is a plethora of information on precipitation chemistry study at the international level, very few can be gleaned from published work about Africa or West African sub- region. However, a report from Nigeria has shown a study of Rainwater quality from different roof catchments in Port Harcourt District (Uba and Aghogho, 2001). The results showed that the physico-chemical qualities of rainwater were within the limits approved by WHO. An alkaline pH (7.02 - 7.45) was obtained in all the samples. In Nigeria, especially in the Niger Delta, a review of literature and existing environmental reports showed that few studies (Seems, 1995; UNICAL, 1994; IPS, 1991; PRODEC, 1994; LANKIN, 1995) carried out in the Niger Delta, addressed precipitation chemistry and that five out of the 88 reports reviewed $(5.7 \%)$ addressed precipitation.

Lankin (1995), studied precipitation chemistry of Mini-Nta as an integral part of a baseline study for Shell East. An average $\mathrm{pH}$ of 6.5 was obtained in the rainy season with a salinity of $36.9 \mathrm{mg} / \mathrm{l}$. PRODEC (1991) carried out precipitation chemistry measurement at nine locations of Shell east facilities as part of gaseous emission study. The physico-chemical analysis covered a wide range of parameters but the precipitation result was not included in the report. The Institute of Pollution Studies (1991) also carried out precipitation chemistry measurement at four sites in Rivers State as part of a study. Preliminary report did not detect sulphate in the rain water.

Unical Consultancy Services carried out an acid rain study for Shell East at nine locations covering Akwa Ibom and Rivers States. Results covering over 45 rain samples showed presence of alkaline rain with mean site $\mathrm{pH}$ varying from $5.88-7.3 \mathrm{pH}$ values lower than 5.6 were however observed in the months of August and September only and varied from $5.10-7.22$. It was not clear if sampling was of event or bulk precipitation type. 
Seems (1995), carried out a comprehensive acid rain study for Shell West at sixteen locations in the Niger Delta. The study was carried out in the western part of the Niger Delta and the result showed existence of acid rain with $\mathrm{pH}$ values ranging from 3.3 - 6.2 for over 100 samples analyzed during the study period. Apart from $\mathrm{NO}_{3}{ }^{-}$and $\mathrm{SO}_{4}{ }^{2}$ being found as contributors to acidity, strong contribution was also observed to come from organic acids identified as acetic, butyrate and propanoic acids.

Further review of literature showed that the EIA of Delta Steel at Aladja executed by the University of Ibadan Consultancy Services in 1985 also had chemical analysis of the wet deposition around Warri and Ajaokuta in which acid rain fingerprints like $\mathrm{pH}, \mathrm{SO}_{4}{ }^{2-}$ and $\mathrm{NO}_{3}{ }^{-}$were measured (Seems, 1995). Adeniyi (1987), also measured the wet deposition at Ororokpe in Delta State by event basis and their chemical analysis included $\mathrm{pH}$, cations and anions (Seems, 1995).

There is paucity of information on precipitation study in the eastern Niger Delta, especially Port Harcourt where it is widely believed in some circles that rain is acidic presumably because of the numerous flaring activities of the oil industry. Much of the work to date has been done in the west of the Niger Delta and few done in East (Faithlink, 2001; SPDC, 1994) are ad hoc studies, generally limited to oil companies and tailored to suit their needs.

Precipitation studies are essential and critical to the understanding of aerosol chemistry in the Niger Delta where the bulk of the flaring activities exist, besides additional automobile sources. There is need to generate information that will stimulate research and provide more understanding in this direction.

\section{Materials And Methods}

Three sampling sites were selected for the collection of precipitation samples based on accessibility, ease of sample collection and low risk of vandalism. The GPS locations are given in Table 1.

Table 1: Study locations and their GPS Points for precipitation studies

\begin{tabular}{|l|l|l|l|}
\hline No & Station & GPS N & GPS E \\
\hline 1. & IPS Laboratory environ & $4^{\circ} 47^{\prime} 29.470^{\prime \prime}$ & $6^{\circ} 58^{\prime} 49.925^{\prime \prime}$ \\
\hline 2. & Eagle Island & $4^{\circ} 47^{\prime} 03.400^{\prime \prime}$ & $6^{\circ} 59^{\prime} 04.100^{\prime \prime}$ \\
\hline 3. & Stadium Road environ & $4^{\circ} 49^{\prime} 13.650^{\prime \prime}$ & $7^{\circ} 50^{\prime} 59.600 "$ \\
\hline
\end{tabular}

'Wet' only precipitation samples were collected (free fall) on an "event" basis. This means precipitation sampling taken on a non-routine basis i.e. single precipitation event. Since it is essential for this mode of sampling that the collection procedure results in samples of wet deposition only not bulk samples (which consist of wet deposition plus materials that have entered the collector during dry periods (WMO, 1998). The precipitation samples were therefore collected during the period of rain only.

A manual method was used utilizing simple polyethylene buckets and bottles of about 2 liters for storing samples before transfer to the laboratory for analysis. Field samples were preserved and stored in a cool and dry place before sending to the laboratory for analysis. The collection bottles were thoroughly rinsed with distilled water. The same procedure was used for the sample bucket and containers. These were placed about $1 \frac{1}{2}$ meters high above splash level, in a position just before the onset of rain and removed either within 5 minutes after rain ceases to fall or first thing the next morning.

This sampling protocol ensured that the rain water was sampled in a wet - only mode as far as possible. A few drops of chloroform were added to the collection bucket for $\mathrm{pH}$ sample only or the sample on retrieval for preservation. Samples without this preservation method were not considered as valid samples for the measurement of $\mathrm{pH}$.

The following parameters were analyzed and recorded following WMO (1988) protocols and Standard Methods (APHA, 1995). All data collected for all the rain events were collated and statistically analyzed. The parameters are:

$\mathrm{pH}$, Total Dissolved Solids, TDS; Sulphate, $\mathrm{SO}_{4}{ }^{2-}$; Nitrate, $\mathrm{NO}_{3}{ }^{-}$; Chloride, $\mathrm{Cl}^{-}$, Ammonium ion, $\mathrm{NH}_{4}^{+}$; Alkalinity; Conductivity; etc. 


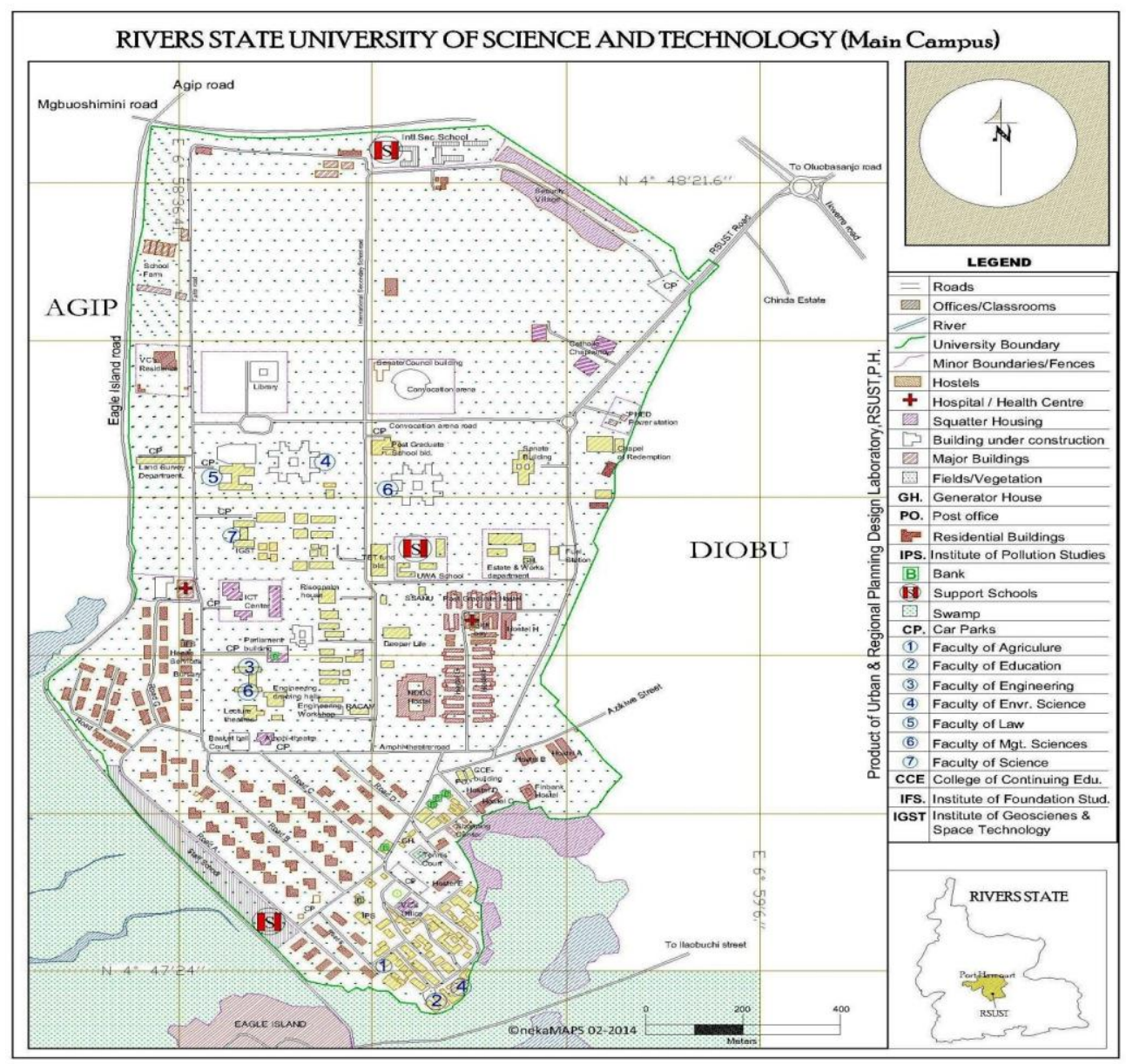

Source: Urban \& Regional Planning Dept. RSUST, P.H.

Fig. 1: The Map of RSUST showing the sampling stations

\section{Results}

The results of rain water quality from RSUST campus and adjoining environs are presented in Table 2. The rain water $\mathrm{pH}$ was 6.46 . Oxidation reduction potential (ORP) ranged from +29 to +126 with a mean of $+73.5 \pm 41.8 \mathrm{mV}$ for campus; +65 to $+70(+67.5 \pm 3.5) \mathrm{mV}$ for Stadium Road and $+126.0 \mathrm{mV}$ for Eagle Island Station. The temperature ranged from $24.6-29.6{ }^{\circ} \mathrm{C}$ across all stations with a mean of $28.5 \pm 1.2^{\circ} \mathrm{C}$.

The Conductivity varied from $3.83-29.4(16.3 \pm 11.0) \mu \mathrm{S} / \mathrm{cm}$ on Campus, $5.2-22.2(18.7 \pm 12.02) \mu \mathrm{S} / \mathrm{cm}$ from Stadium road and $10.95 \mu \mathrm{S} / \mathrm{cm}$ at Eagle Island. The means ranged from $10.95-18.7 \mu \mathrm{S} / \mathrm{cm}$ with the lowest coming from Eagle Island. Salinity ranged from $<0.01-0.01 \%$ at all sites except Eagle Island where levels were not detected.

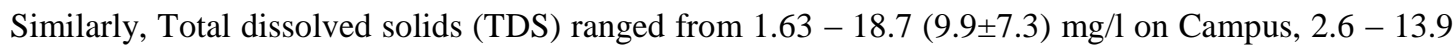
$(8.23 \pm 8.0) \mathrm{mg} / \mathrm{l}$, at Stadium Road and $6.34 \mathrm{mg} / \mathrm{l}$ at Eagle Island (Table 2.). Their means ranged from $6.34 \mathrm{mg} / \mathrm{l}$ at Eagle Island to $9.9 \mathrm{mg} / \mathrm{l}$ on Campus, with a high standard deviation.

Dissolved Oxygen ranged from 5.7 - $7.3(6.5 \pm 1.1) \mathrm{mg} / \mathrm{l}$ within campus air shed, while in Stadium air basin, it was $6.5 \mathrm{mg} / \mathrm{l}$. There was no data for Eagle Island.

The Chloride values ranged from not detected $<1.0-1.4 \mathrm{mg} / \mathrm{l}$ on Campus in a single event and not detectable in Eagle Island and Stadium road environs. Sulphate and Phosphates were not detected being less than $1.0 \mathrm{mg} / \mathrm{l}$ and $0.05 \mathrm{mg} / \mathrm{l}$ respectively. In contrast, Nitrate levels varied from $0.23-1.1(0.6 \pm 0.4) \mathrm{mg} / \mathrm{l} \mathrm{on}$ Campus air basin whereas, the others, Stadium Road and Eagle Island had 0.31 and $0.41 \mathrm{mg} / \mathrm{l}$ respectively.

Ammonia concentration ranged from $<0.02-0.90 \mathrm{mg} / \mathrm{l}$ with a mean of $0.32 \pm 0.4 \mathrm{mg} / \mathrm{l}$ in campus air basin whereas Stadium Road and Eagle Island had 0.21 and $0.09 \mathrm{mg} / \mathrm{l}$ respectively. Total Hardness ranged from $<0.2$ $-5.8 \mathrm{mg} / \mathrm{l}$ on campus air basin, while it was $<0.2 \mathrm{mg} / \mathrm{l}$ in Eagle Island. Alkalinity ranged from $8.0-12.0 \mathrm{mg} / \mathrm{l}$ with a mean of $10.7 \pm 2.3 \mathrm{mg} / \mathrm{l}$ on Campus air basin while in Eagle Island; it was $12.0 \mathrm{mg} / \mathrm{l}$ (Table 2). 
Precipitation Chemistry of the Rivers State University of Science and Technology (RSUST) ...

Table 2: Rain Water Results as determined on Campus and Adjoining Environs in October, 2013.

\begin{tabular}{|c|c|c|c|c|}
\hline & & RW1 IPS/RSUST & RW2 Std. RD. & RW3 EI \\
\hline No. & Parameters & & & \\
\hline 1. & $\mathrm{pH}$ & - & - & 6.46 \\
\hline 2. & ORP $(\mathrm{mV})$ & $29-126(73.5 \pm 41.8)$ & $65-70(67.5 \pm 3.5)$ & 126.0 \\
\hline 3. & Temperature ${ }^{\circ} \mathrm{C}$ & $24.6-29.6(27.6 \pm 2.3)$ & $27.7-27.9(27.8 \pm 0.1)$ & 27.6 \\
\hline 4. & Conductivity $(\mu \mathrm{S} / \mathrm{cm})$ & $3.83-29.4(16.3 \pm 11.0)$ & $5.2-22.2(18.7 \pm 12.02)$ & 10.95 \\
\hline 5. & Salinity (\%o) & $<0.01-0.01$ & $<0.01-0.01$ & $<0.01$ \\
\hline 6. & Resistivity $(\mathrm{k} \Omega)$ & $33.8-264(108.2 \pm 106.0)$ & $45.3-91.9(32.2 \pm 8.5)$ & 91.9 \\
\hline 7. & Dissolved oxygen (mg/l) & $5.7-7.3(6.5 \pm 1.1)$ & $6.5-6.5(6.5)$ & - \\
\hline 8. & Total dissolved solid (mg/l) & $1.63-18.7(9.9 \pm 7.3)$ & $2.6-13.9(8.23 \pm 8.0)$ & 6.34 \\
\hline 9. & Total hardness $\left(\mathrm{mg} / \mathrm{l}\right.$ as $\left.\mathrm{CaCO}_{3}\right)$ & $<0.2-5.8(3.0 \pm 4.0)$ & - & $<0.2$ \\
\hline 10. & Alkalinity $\left(\mathrm{mg} / \mathrm{l}\right.$ as $\left.\mathrm{CaCO}_{3}\right)$ & $8.0-12.0(10.7 \pm 2.3)$ & - & - \\
\hline 11. & Chloride as $\mathrm{Cl}^{-}(\mathrm{mg} / \mathrm{l})$ & $<1.0-1.4(1.1 \pm 0.2)$ & - & $<1.0$ \\
\hline 12. & Sulphate as $\mathrm{SO}_{4}^{-2}(\mathrm{mg} / \mathrm{l})$ & $<1.0$ & $<1.0$ & $<1.0$ \\
\hline 13 & Phosphate as $\mathrm{PO}_{4}^{-3}(\mathrm{mg} / \mathrm{l})$ & $<0.05$ & $<0.05$ & $<0.05$ \\
\hline 14 & Nitrate as $\mathrm{NO}_{3}{ }^{-}(\mathrm{mg} / \mathrm{l})$ & $0.23-1.11(0.6 \pm 0.4)$ & 0.31 & 0.41 \\
\hline 15 & Ammonia & $<0.02-0.9(0.3 \pm 0.4)$ & 0.21 & 0.09 \\
\hline 16 & Calcium as $\mathrm{Ca}(\mathrm{mg} / \mathrm{l})$ & $<0.08-1.2(1.2)$ & $<0.08$ & $<0.08$ \\
\hline 17 & Magnesium as $\mathrm{Mg}(\mathrm{mg} / \mathrm{l})$ & $<0.05-0.7(0.7)$ & - & $<0.05$ \\
\hline
\end{tabular}

RW- Rain Water

Calcium concentration varied from $<0.08-1.2 \mathrm{mg} / \mathrm{l}$ in campus air basin while in others, it was less than $0.08 \mathrm{mg} / \mathrm{l}$. Similarly, Magnesium ranged from $<0.05-0.7 \mathrm{mg} / \mathrm{l}$ and less than $<0.05 \mathrm{mg} / \mathrm{l}$ in the other two air basins.

Correlation analysis showed strong and significant negative relationship between Resistivity, DO, TDS with Temperature while Conductivity, Total Hardness, Chloride, Calcium and Magnesium showed significant relationship with Temperature (Fig. 2). Similarly, strong significant and positive relationship/ correlation were observed between Total Hardness, Chloride, Calcium, Magnesium, Conductivity and Temperature. Similarly, strong significant and positive relationship/ correlation were observed between Total Hardness, Chloride, Calcium, Magnesium, Conductivity and Temperature.

Dissolved Oxygen showed a strong negative and significant relationship with Total Alkalinity and Nitrate. Strong and positive relationships were also observed between Total Alkalinity and Nitrate, Chloride and Nitrate, Nitrate and Calcium, Nitrate and Magnesium. pH only correlated negatively with Oxidation Reduction Potential (ORP). Apart from Nitrate, Ammonium ion and Total Alkalinity, all the other ions had either a negative or positive correlation with Temperature (Fig.1). Ammonia did not correlate with any ion.

Analysis of variance showed statistics to be greater than $F$ critical $\left[F_{\text {stat }}(9.670)_{.05}>F_{\text {cri }}(1.848)_{.05}\right]$ for columns/parameter while for rows/stations, differences were not significant $\left[F_{\text {stat }}(1.977)_{.05} \geq F_{\text {cri }}\left(2.217_{.05}\right]\right.$.

Table 3 : Anova - Two-Factor Without Replication at 95\%

\begin{tabular}{|l|l|l|l|l|l|l|}
\hline Source of Variation & $S S$ & $d f$ & $M S$ & $F$ & $P$-value & F crit \\
\hline Rows/ stations & 9741.159 & 6 & 1623.526 & 1.977 & 0.079 & 2.217 \\
\hline Columns/ parameters & 103223.877 & 13 & 7940.298 & 9.670 & $1.28 \mathrm{E}-11$ & 1.848 \\
\hline Error & 64045.883 & 78 & 821.101 & & & \\
\hline Total & 177010.919 & 97 & & & & \\
\hline
\end{tabular}

\section{Discussion}

The $\mathrm{pH}$ of 6.46 shows rain water is alkaline and not acidic, though it came from a single event. In atmospheric chemical study, $\mathrm{pH}$ less than 5.6 is taken as acidic while $\mathrm{pH}$ greater than 5.6 is taken as alkaline (Mamane et al., 1987). The $\mathrm{pH}$ of 5.6 is often quoted as a reference value for precipitation. This value of 5.6 is that of a weak carbonic acid solution formed in cloud water or rain water when in equilibrium with ambient $\mathrm{CO}_{2}$ concentration found in the lower atmosphere (WMO, 1989). The term, acid precipitation is commonly used for precipitation with high concentrations not only of hydroxonium ions but also of sulphate, nitrate and ammonium ions (NIRP, 1981).

This result though from a single rain event measurement, corroborates the findings of previous studies on rain water chemistry done in the Eastern Niger Delta, where $\mathrm{pH}$ values ranging from 6.0 to as high as 8.0 were obtained (Unical, 1994; Lankin, 1995; Faithlink, 2001 and Ubong, 2008).

Precipitation has been shown in the literature not to be acidic everywhere (Mamane et al., 1987). While some places record acidic deposition, (for example, North East of United States of America, Europe, some parts of Japan, China, Brazil, Argentina, South East of Australia, etc), others record alkaline deposition (e.g. Israel, arid and semi-arid regions such as the Midwest, West and South-west United States; India, other sites mainly along the World Desert belt, etc) (Mamane, et al.,1987; WMO, 1989; Subramanian and Saxena,1980; Doty, and Semonin,1984). 
The temperature range of $24.6-29.6{ }^{\circ} \mathrm{C}$ across all stations with mean ranging from $27.6-27.8{ }^{\circ} \mathrm{C}$ is considered satisfactory for rain water as it reflected the prevailing weather condition at the time. The maximum value of ORP $(+126.0 \mathrm{mV})$ for Campus and Eagle Island Stations, was similar but higher than that of Stadium Road environ $(+70 \mathrm{mV})$. This observation is attributed to the fact that both Campus and Eagle Island are close to a river, while stadium road is hinter-land. ORP is a measure of the relative oxidizing and reducing power of a solution and can be positive or negative.

Total Dissolved Solids (TDS) mean across air basins $(6.34-9.9 \mathrm{mg} / \mathrm{l})$ showed uniformity of atmospheric composition. Electrical Conductivity is related almost linearly to the TDS concentrations in precipitation. The low value of Conductivity at Eagle Island may be attributed to vegetative cover. Conductivity, or specific conductance, is a measure of the ability of water to conduct an electric current. It is sensitive to variations in Total Dissolved Solids (TDS) (Table 4.1), mostly mineral salts. The degree to which these dissociate into ions, the amount of electrical charge on each ion, ion mobility and the temperature of the solution all have an influence on conductivity.

The low salinity obtained is a reflection of the low TDS and Electrical Conductivity. Salinity has to do with the amount of salt carried by the air masses associated with the rain. This implies that the amount of salt carried by the air masses was low at the time of sampling.

\section{Nitrate}

The least nitrate concentration $(0.31 \mathrm{mg} / \mathrm{l})$ measured at Stadium Road showed that nitrate concentrations are higher close to brackish water area than the hinterland. Nitrate in rain arises from the hydrolysis of nitrogen dioxide $\left(\mathrm{NO}_{2}\right.$ emanating from lightening, combustion processes, local sources, etc.

Nitrogen compounds in precipitation are equally important. A long series of observations in England, since 1900, showed an unmistakable long-term increase in their concentrations; a similar trend was reported in Europe and North America for the last 15 years (WMO, 1989). The major source of these compounds is the synthesis of nitrogen oxides from atmospheric nitrogen and oxygen during combustion at high temperatures. These oxides later appear in precipitation as nitrate. Nitrate is also formed from bush fires, lightening and soil emissions (Ayers and Gillett, 1988).

When influenced by man's activities, surface waters normally contain nitrate concentrations up to 5 $m g 1^{-1} \mathrm{NO}_{3} \mathrm{~N}$, but often less than $1 \mathrm{mg}^{-1} \mathrm{NO}_{3} \mathrm{~N}$. Levels in excess of $5 \mathrm{mg} 1^{-1} \mathrm{NO}_{3} \mathrm{~N}$ usually indicate pollution by human or animal waste, or fertilizer run-off. In cases of extreme pollution, concentrations may reach $200 \mathrm{mg} 1^{-1}$ $\mathrm{mg} \mathrm{N} \mathrm{N}_{3} \mathrm{~N}$. As the World Health Organization (WHO) recommended maximum limit for drinking water is 10 $\mathrm{mg}^{-1} \mathrm{NO}_{3} \mathrm{~N}$, waters with higher concentrations represent a significant health risk. In lakes, levels of nitrate in excess of $0.2 \mathrm{mg}^{-1} \mathrm{NO}_{3} \mathrm{~N}$ tend to stimulate algal growth and indicate possible eutrophic conditions (UNESCO/WHO/UNEP, 1992). Sulphate was not detected in this study. This clearly shows non contribution from anthropogenic sources. This could be as a result of the low Sulphur content of fuel burnt in Nigeria (Egbuna, 1987). One of the most important constituents of precipitation is sulphate. The presence of Sulphate to a large extent, particularly on the regional scale, is due to human activities, notably the combustion of fossil fuels, which release sulphur dioxide into the atmosphere with subsequent oxidation to sulphate (WMO, 1988).

Both sulphate and nitrate, derived through the processes outlined above, become strong acids when incorporated into precipitation; therefore, they are able to lower the $\mathrm{pH}$ of precipitation. Values of $\mathrm{pH} 3$ have been found on occasions in rural parts of Europe and North America but in this study, it was not detectable.

The maximum chloride level of $1.4 \mathrm{mg} / \mathrm{l}$ observed at one instance is explained by the South Westerlies winds that blow across the Atlantic bringing rain; it also carries sea salt moisture which is incorporated into the wind which transports rain to hinter-lands. Chloride is marine derived, being carried as sea water and incorporated into the cloud and deposited inland.

The levels of Ammonium ion varied similar to that of Nitrate (Fig. 2). This is not unexpected because of the relationship between Ammonia and Nitrate. The variation in ammonium ion concentration across the air basins is due to mean meteorological variations, differences in agricultural practices, incineration levels, etc.

Ammonia occurs naturally in water bodies arising from the breakdown of nitrogenous organic and inorganic matter in soil and water, excretions by biota, reduction of the nitrogen gas in water by micro-organisms and from gas exchange with the atmosphere. It is also discharged into water bodies by some industrial processes (e.g. ammonia based pulp and paper production) and also as a component of municipal or community waste and fertilizer run-off (UNESCO/WHO/UNEP, 1992).

Total ammonia concentrations measured in surface waters are typically less than $0.2 \mathrm{mg} / \mathrm{l}$ but may reach $2-3 \mathrm{mg} / \mathrm{l}$. Higher concentrations could be an indication of organic pollution such as from domestic sewage, industrial waste and fertilizer run-off. Ammonia is, therefore, a useful indicator of organic pollution. Natural seasonal fluctuations also occur as a result of the death and nutritionally rich water. High ammonia concentrations may also be found in the bottom waters of lakes which have become anoxic (UNESCO/WHO/UNEP, 1992). Ammonia did not correlate with any ion implying that it had a different source. 
Alkalinity across the air basins $(10.7 \mathrm{mg} / \mathrm{l}$ for Campus and $12.0 \mathrm{mg} / \mathrm{l}$ for Eagle Island) indicate similarity of composition and atmospheric uniformity. This implies that carbonate concentration is fairly stable in the air basins.

Acidity and alkalinity are the base and acid-neutralizing capacities (ANC) of water and are usually expressed as mmoll-. When water has no buffering capacity, they are inter-related with $\mathrm{pH}$. The alkalinity of water is controlled by the sum of the titratable bases. It is mostly taken as an indication of the concentration of carbonate, bicarbonates and hydroxides but may include contributions from borates, phosphates, silicates and other basic components. Waters of low alkalinity $\left(<24 \mathrm{mg} / \mathrm{l}\right.$ as $\left.\mathrm{CaCO}_{3}\right)$ have a low buffering capacity (UNESCO/WHO/UNEP, 1992).

Alkalinity is therefore used as a measure of Carbonate and bicarbonate concentrations. Carbonate in precipitation comes from local soils rich in calcites and other carbonates (Mamane, 1987). It has been documented that dust blowing from the Saharan desert towards the Atlantic Coast, is rich in calcites (Granor, 1976; Granor and Mamane, 1982). Carbonates come from calcareous soils (Mamane, 1987).

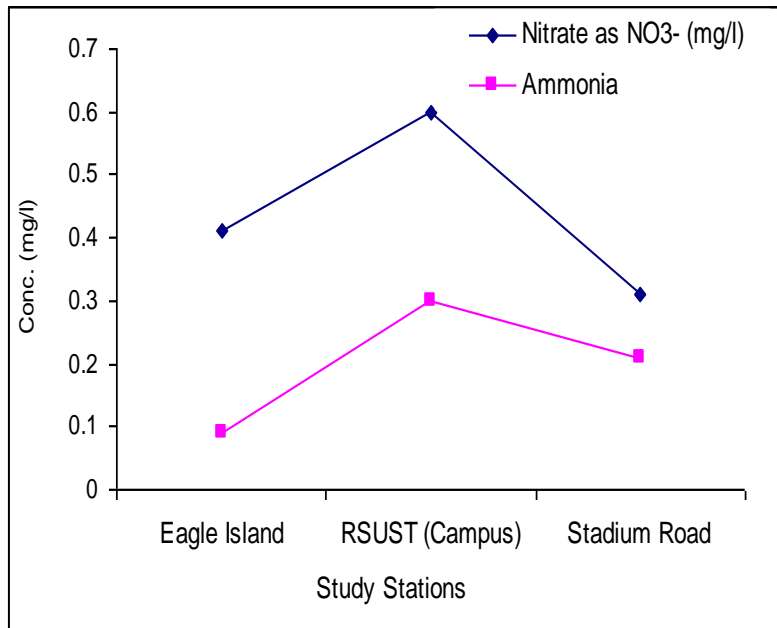

Fig. 2: Variations of Ammonia and Nitrate in the Study Air Sheds

The hardness of precipitation or natural waters depends mainly on the presence of dissolved Calcium and Magnesium salts. The total content of these salts is known as general hardness (UNESCO/WHO/UNEP, 1992). In precipitation, $\mathrm{Ca}^{2+}$ and $\mathrm{Mg}^{2+}$ may be continentally derived.

Hardness in precipitation or water is generally caused by the presence of calcium or magnesium ions. Metal ions of calcium and magnesium are generally not considered as pollutants. Sodium, Magnesium and Chloride are largely derived from sea spray in ocean areas. Calcium and Potassium originate from deserts and from semi-arid regions and from intensely cultivated areas (WMO, 1988).

The strong and significant correlation observed between Chloride and Nitrate ( $\mathrm{r}=0.803)$, Hardness with Nitrate $(\mathrm{r}=0.803)$, Nitrate with $\mathrm{Ca}$ and $\mathrm{Mg}(\mathrm{r}=0.803)$ and Nitrate with Alkalinity as $\mathrm{CaCO}_{3}(\mathrm{r}=0.765)$ show that they have the same source probably from soil or marine. This suggests the continental route, as the possible source of Nitrate either as Nitrogen dioxide produced from microbial activities which later dissolve in rain water to form Nitrate or from waste decomposition. The non-correlation between $\mathrm{pH}$ and $\mathrm{NO}_{3}{ }^{-}$implies that Nitrate is not responsible for the $\mathrm{pH}$ observed.

Conductivity varied similar to the trend found in Calcium and Magnesium. The highest Conductivity value $(18.7 \mu \mathrm{S} / \mathrm{cm})$ obtained at Stadium Road (hinterland) could be attributed to the presence of Total Dissolved Solids that are ionizable such as Calcium, Magnesium, Alkalinity, Hardness, etc.

Conductivity is a measure of the ability of water to conduct an electric current. It is sensitive to variations in Total Dissolved Solids (TDS) mostly mineral salts. The degrees to which these dissociate into ions, the amount of electrical charge on each ion, ion mobility and the temperature of the solution all have an influence on conductivity. Conductivity is expressed as micro-siemens per centimeter $\left(\mu \mathrm{Scm}^{-1}\right)$ for a given water body. Conductivity is related to the concentrations of Total Dissolved Solids (TDS) and major ions in precipitation. The correlation of Conductivity with many ions shows the ions that contribute to the Conductivity.

The differences in Total Dissolved Solid contents across the air basins with the highest mean $(9.9 \mathrm{mg} / \mathrm{l})$ on Campus could be attributed to differences in meteorology. Total Dissolved Solids are a measure of the dissolved salts constituent in water whether precipitation or surface water. It is generally proportional to conductivity. 
Sulphate was not detected in precipitation in this study. The non-detection of Sulphate shows noncontribution from anthropogenic sources. Anova results indicated that there was no significant differences between stations $(\mathrm{p} \leq .05)$, while differences between parameters were significant $(\mathrm{p} \geq 05)$. It can then be concluded that the rain water quality on RSUST Campus is alkaline (pH 6.46). The study did not show any contribution from anthropogenic sources; that natural sources (soil minerals) are the main contributors to rain chemistry.

The study is significant in that it has provided information on the state of the chemical composition of rainfall, the $\mathrm{pH}$ status of rain water and the need for further study.

\section{Acknowledgement}

The authors are grateful to the Institute of Pollution Studies (IPS), Rivers State University of Science and Technology, Port Harcourt, Nigeria, for providing the platform that led to this study.

\section{References}

[1]. Ayers, G. P. and Gillett, R.W. (1988). Acidification in Austrialia. In: H. Rodhe and R. Herrera (Eds), Acidification in Tropical Countries. John Wiley and Sons, Chichester, England, Scope, 36: 347-400.

[2]. APHA, 1995. Standard Methods for the Examination of Water and Wastewater. 19 ${ }^{\text {th }}$ edn. APHA, AWWA, WPCF, American Public health Association Washington. DC.

[3]. Ayoade, J. O. 1988. Introduction to climatology for the tropics, John Wiley.

[4]. Cowling, E. B.1982. Acid precipitation in historical perspective. Environmental Science Technology 16: 1109 - 1239.

[5]. Davies, T. D; P. W. Abrahans; M. Transfer; I. Blackwood; P. Briuble Combe and C.E. Vincent. 1984. Black acidic snow in the remote Scottish highlands. Nature, 312: 58-61.

[6]. Dayan, U, Mamane, Y. and Miller, J. 1986. Sources of alkaline and acidic contribution to precipitation in Israel. Presented at the inter, symposium on acidic precipitation, Muskoka, Ontario Canada, 15 -20 September 1985.

[7]. Doty, K. E. and R. G. Semonin. 1984. A case study of the effect of distant and local sources of alkaline materials on precipitation in the Midwest and plains. Paper $84-203$ presented at the $77^{\text {th }}$ Annual Meeting of APCA, San Francisco, CA $24-29$ June.

[8]. Faithlink, (2001). Faithlink Consult Nigeria Ltd. The Air Quality, Precipitation and Corrosion studies of QIT flare and the Environs. A final Technical Report, submitted to The Environmental Affairs Dept. Mobil Producing Nig. Unltd., QIT, Eket.

[9]. Felly, J. A. and H. M. Liljestrand 1983. Source contributions to acid precipitation in Texas. Atmos. Environ, 17:807-814.

[10]. Fowler, D. 1980. Removal of Sulphur and Nitrogen compounds from the atmosphere in rain and by dry deposition. In: Drablos, D. and Tollan, A. (eds): Ecological impact of acid precipitation, p. 22-32, SNSF-project.

[11]. Galbally, I. E. 1975. Emission of oxides of nitrogen $\left(\mathrm{NO}_{\mathrm{X}}\right)$ and ammonia from the earth's surface. Tellus 27-67-70.

[12]. Galloway, J. N; Miller, J. M.; Likens, G. E. and William, C. K. (1985). A summary of results from the global precipitation chemistry project. World Meteorological Organization Special Environmental Report, No. 16. Lectures presented at the WMO Technical Conference of Atmospheric Contaminants, TECOMAC, Vienna.

[13]. Galloway, J. N; G. E. Likens and E. S. Edjerton. 1976. Acid precipitation in North Eastern Unites States. pH and Acidity. Science 194: $722-724$.

[14]. Gillett, R. W., Ayers, G. P., Noller, B.N. (1990). Rainwater Acidity at Jabiru, Australla, in the wet season of 1983/84. The Science of the Total Environment, 92:129 -144.

[15]. IPS, 1991.The effects of gas flares on the Rivers State environment. A Technical Report submitted by the institute of pollution studies, Rivers State University of Science and Technology, Port Harcourt.

[16]. Khemani, L. T. G, A. Monin, M. S. Naik; P. S Prakasarao; R. Kumar and B. H. V. Ramana Murty. 1985. Impact of alkaline particulates on $\mathrm{pH}$ of rain water in India. Water, Air, Soil, pollut., 25: $365-376$.

[17]. Likens, G. E. 1976. Acid deposition, Cgem. Eng. News, 54: $29-44$.

[18]. Likens, G. E. and T. J. Buttler. 1981. Recent acidification of precipitation in North America. Atmos environ, 15: 1103- 1109.

[19]. Liljestrand, H. M. and J.S. Morgan. 1979. Error analysis applied to indirect methods for precipitation acidity. Tellus, $31: 421-431$.

[20]. Lankin, 1995: A Baseline ecological study of the Mini-Nta Field. A Technical Report by Lankin Nigerian, Port Harcourt, submitted to Shell Petroleum Development Company of Nigeria Limited.

[21]. Mamane, Y;Ganor, E. and Donagi, A. E. (1980). Aerosol composition of urban and desert origin Mamane, Y. 1987. The Chemistry of Precipitation in Israel. The Sc. of the Total Env. 61, $1-13$.

[22]. Mamane, Y., Dayan, U; Miller, J .M. 1987. The contribution of alkaline and acidic sources to precipitation in Israel. The Science of the Total Environment. Vol. 61, $15-14$.

[23]. Miller, J. M; Richard, S. Artz, (1985). Analysis of Precipitation Chemistry Data at US/WMO/NADP sites. WMO Special Environmental Report No. 16.

[24]. NADP. 1989. National Atmospheric Deposition Programme. Precipitation chemistry in the United States. NADP/NTN Annual data summary. Coordination Office, National Resource Ecology Laboratory, Colorado State University.

[25]. NIRP. (1981). The Norwegian Interdisciplinary Research Program; Acid Precipitation - Effects on Forest and Fish. The SNSF project. Final Report of the Oslo.

[26]. PRODEC, 1991. The assay of gaseous emissions of selected facilities in SPDC (East) operational area. Submitted to the Shell Petroleum Development Company of Nigeria East.

[27]. Reynolds, B. 1984. An assessment of spatial variation of chemical composition of bulk precipitation within an upland catchment. Water Resources Pes 20: $733-735$

[28]. Reynolds, B. T., Williams, G. and Stevens, P.A. (1990). The chemical composition of Bulk precipitation across the mountains of Snowdonia,

[29]. Seems, 1995. A Final report on acid rain studies (20 km radius of Utorogu Gas Plant). Submitted to SPDC West by Seems Nig. Ltd, 110 Awolowo Way, Lagos.

[30]. Sequira, R. A. and D. N. Kelkar. 1978. Geochemical Implications of summer monsoonal rain water composition over India J. Appl Meteorol 17:1390-1396.

[31]. Sequeira R. A. 1982 The Chemistry of precipitation at high altitudes: inter-relation of acid base components, Atmos. Environ., 16: $329-335$. 
[32]. Stensland G.J. 1983 Wet deposition network data with applications to selected problems chapter 8.4, in EPA Report $600 / 8$-83$616 \mathrm{~A}$ - the acidic deposition phenomenon of $\mathrm{N}$ and its effects. US EPA Washington DC.

[33]. Stensland, G. Z. and Semonin, R. G. (1982). Another Interpretation of pH trend in the United States. Bull. Am. Meteorol. Soc. 63:1277-1284.

[34]. Summers, P. W. (1985). A review of Airborne Precipitation Chemistry Measurements and the implications for Global Chemical Climatology. World Meteorological Organization Special Environmental Report, No. 16. Lectures presented at the WMO Technical Conference of Atmospheric Contaminants, TECOMAC, Vienna.

[35]. SPDC 1994: Environmental study to investigate the relationship between Gas flaring and acid Rain. A Final Technical report submitted to Shell Petroleum Development Company, East, Port Harcourt.

[36]. SPDC. (1994). Environmental study to investigate the relationship between Gas flaring and acid Rain. A Final Technical report submitted to Shell Petroleum Development Company, East, Port Harcourt.

[37]. Subramanian, V. and K. K. Sarena. 1980. The Chemistry of monsoon rainwater at Delhi, tellus $32558-661$.

[38]. Seems. (1995). Seems Nig. Ltd. A Final report on acid rain studies (20 km radius) of Utorogu Gas Plant. Submitted to SPDC West by Seems Nig. Ltd, 110 Awolowo Way, Lagos.

[39]. IPS, (1991). Institute of Pollution Studies. The effects of gas flares on Rivers State environment. A Technical Report submitted by the Institute of Pollution Studies, Rivers State University of Science and Technology, Port Harcourt, to the State Ministry of Environment.

[40]. PRODEC. (1991). The assay of gaseous emissions of selected facilities in SPDC (East) operational areas. A technical report submitted to Shell Petroleum Development Company of Nigeria, East, Port Harcourt.

[41]. Uba, B. N., Onakwe, A. (2001). Rain water Quality from Different Roof Catchments in Port Harcourt District. IPAN News. Vol. 2, No.6.

[42]. Ubong, I. U. 2008. The Chemistry of precipitation in Port Harcourt and the environs. A Ph.D. thesis submitted to the Post graduate School, Federal University of Technology, Owerri.

[43]. Unical Consult.(1994). University of Calabar Consultancy Services Environmental study to investigate the relationship between Gas flaring and acid Rain. A Final Technical report submitted to Shell Petroleum Development Company, East, Port Harcourt.

[44]. UNESCO/WHO/UNEP. (1992). Water Quality Assessments. A guide to the use of Biota, Sediments and water in Environmental Monitoring. Edited by Doborah Cahpman, Chapman and Hall Ltd, 2-6 Boundary Rav., London.

[45]. WMO, 1979. WMO Symposium on the long range transport of pollutants and its relation to general circulation including stratospheric /tropospheric exchange processes. WMO 538.

[46]. WMO, 1988, International operations handbook for measurement of background Atmospheric pollution, WMO-No. 491, World Meteorological Organization, Geneva, Switzerland. $110 \mathrm{PP}$

[47]. WMO, 1989: Fact sheet No. 5: Gaws and precipitation chemistry measurement Activities, World Meteorological Organization, Geneva.

[48]. WHO, 2002. World health report 2002. Reducing risks, promoting healthy life. Geneva, World Health Organization, 2002.

\begin{tabular}{|c|c|c|c|c|c|c|c|c|c|c|c|c|c|c|}
\hline & $p H$ & $O R P$ & Tempt. & cond. & Resis. & $D O$ & IDS & T. HARD. & T. ALK. & $C L^{-}$ & $\mathrm{NO}_{3}$ & $\mathrm{NH}_{\mathrm{t}^{+}}$ & $\mathrm{Ca}$ & $\mathrm{Mg}$ \\
\hline $\mathrm{pH}$ & 1 & & & & & & & & & & & & & \\
\hline Tempt. & 0.436 & -0.568 & 1 & & & & & & & & & & & \\
\hline Do & -0.467 & 0.057 & -0.709 & -0.319 & 0.508 & 1 & & & & & & & & \\
\hline IDS & -0.190 & 0.566 & -0.803 & -0.430 & 0.739 & 0.439 & 1 & & & & & & & \\
\hline T. HARD. & -0.167 & 0.070 & 0.516 & 0.681 & -0.382 & -0.467 & -0.101 & 1 & & & & & & \\
\hline NO3- & 0.192 & 0.145 & 0.341 & 0.496 & -0.261 & -0.611 & 0.204 & 0.803 & 0.765 & 0.803 & 1 & & & \\
\hline $\mathrm{NH} 4+$ & -0.201 & -0.348 & 0.027 & 0.566 & -0.556 & 0.100 & -0.268 & 0.092 & -0.379 & 0.092 & -0.075 & 1 & & \\
\hline $\mathrm{Ca}$ & -0.167 & 0.070 & 0.516 & 0.681 & -0.382 & -0.467 & -0.101 & 1.000 & 0.417 & 1.000 & 0.803 & 0.092 & 1 & \\
\hline $\mathrm{Mg}$ & -0.167 & 0.070 & 0.516 & 0.681 & -0.382 & -0.467 & -0.101 & 1.000 & 0.417 & 1.000 & 0.803 & 0.092 & 1 & 1 \\
\hline
\end{tabular}

Fig. 1: Correlation matrix of ions in rain water 